\title{
Resistance of Phosphogypsum Cement Pozzolanic Compositions against the Influence of Water
}

\author{
Sergejus GAIDUČIS ${ }^{1}{ }^{*}$, Jadvyga ŽVIRONAITÉ ${ }^{1}$, \\ Romualdas MAČIULAITIS ${ }^{1}$, Grigorij JAKOVLEV ${ }^{2}$ \\ ${ }^{1}$ Vilnius Gediminas Technical University, Saulètekio 11, LT-102223 Vilnius, Lithuania \\ ${ }^{2}$ Izhevsk State Technical University, Studencheskaya St. 7, 426069 Izhevsk, Russia \\ crossref http://dx.doi.org/10.5755/j01.ms.17.3.599
}

Received 01 July 2010; accepted 19 March 2011

\begin{abstract}
The reprocessing of freshly removed extractive hemihydrate phosphogypsum into hydraulic composite phosphogypsum cement pozzolana (PGCP) binder using mechanical activation is analyzed in this work. In order to increase the effectiveness of the dealing with phosphogypsum reprocessing problem and to lower the energy consumption required for the production of binding materials from phosphogypsum, physical mechanical and water resistance properties of the PGCP binder with less amount (10\%) of cement (PGCP(10)) were analyzed and compared with the properties of conventional PGCP binder, where the amount of cement is $20 \%$ (PGCP(20)). The PGCP binder with pozzolana additives of two types - carbonate opoka and microsilica are analysed. Fresh wet hemihydrate phosphogypsum, cement and pozzolana additive were mechanically activated together and from resulting mixture the samples were formed by vibrating. Compressive strength of PGCP(10) samples after 28 days was $26 \mathrm{MPa}-29 \mathrm{MPa}$, after 4 months $30 \mathrm{MPa}-32 \mathrm{MPa}$, PGCP(20) - $32 \mathrm{MPa}-35 \mathrm{MPa}$ and $36 \mathrm{MPa}-42 \mathrm{MPa}$ accordingly. It is found, that hardened PGCP(10) are also quite resistant to short-term (2 days) impact of water (softening coefficient was $0.91-0.94$, however, its resistance to long-term impact of water is significantly less than PGCP(20). PGCP with microsilica is more strength and more resistant to impact of water than PGCP with opoka. Both, PGCP with opoka, as well as the ones with microsilica, are resistant to the formation of ettringite. However, the primary ettringite and high amount of carbonates, found in the PGCP with opoka, stimulates the formation of thaumasite at low positive temperature and humidity.

Keywords: phosphogypsum, cement, pozolana, composite binder, mechanical activation.
\end{abstract}

\section{INTRODUCTION}

Gypsum binding materials are distinguished by fast hardening, and their products are characterized by high strength, low heat and sound conductance, large chemical resistance, resistance to fire, and can be used for the decoration. However, these products due to melting of the contact of hardened gypsum crystals are not resistant to water - the strength of moistened products reduces by $2-3$ times. Phosphogypsum products are extremely nonresistant to the influence of water, because the particles of phosphogypsum have irregular fine crystal structure, are porous, and large amounts of water are required for its mixing [1-3]. Water resistance increases after the additives having hydraulic binding characteristics are added to the binder. One of the best methods is to prepare the gypsum cement pozzolanic compositions (GCP) [4-6]. GCP hardens quickly, and the gypsum framework created is protected by water resistant products of cement hydration. It is known [7-11] that mechanically activated extractive hemihydrate phosphogypsum (PG), contaminated by acidic additives, suitable for the preparation of such compositions. During mechanical activation the particles of PG are uncovered, crystal accumulations are destroyed and the acidic impurities present in capillaries and pores are liberated, thus the neutralization process is intensified. When mechanical activation of PG is carried out together with cement and pozzolanic additive, cement component not only ensures

\footnotetext{
${ }^{*}$ Corresponding author. Tel.: +370-5-2745238; fax.: +370-5-2752629. E-mail address: sergejus.gaiducis@gmail.com (S. Gaidučis)
}

the hydraulic properties for the hardened composition, but also neutralizes the acidic additives, stabilizes the properties of PG and slows down the setting of binder. The activation also increases the strength of PG compositions several times and enable formation of a more dense, consequently, more water resistance structure $[12,13]$. The role of pozzolanic additive is to reduce the amount of available $\mathrm{CaO}$ in liquid phase of hydrating composition and thus avoid the formation of destructive minerals ettringite - in the hardened material. Compositions are regarded to be resistant to sulfate corrosion if the available $\mathrm{CaO}$ concentration in the liquid phase after 5 days is not more than $1.1 \mathrm{~g} / \mathrm{l}$ and $0.85 \mathrm{~g} / \mathrm{l}$ after 7 days [14]. However, even after the proper selection of composition, risk of the formation of other destructive mineral - thaumasite persists at particular conditions (low positive temperature, impact of moisture and $\left.\mathrm{CO}_{2}\right)[15,16]$.

As it is known [4,5], in order to form water resistant GCP composition, the amount of cement in this composition should not be less than $20 \%$. In the work [7] following mechanically activated phosphogypsum cement pozzolana (PGCP) compositions were proposed: $70 \% \mathrm{PG}$, $20 \%$ cement, $10 \%$ microsilica and $60 \%$ PG, $20 \%$ cement and $20 \%$ opoka. In this work PG, which was partially hydrated and had lost binding properties, was used (PG properties are tightly related to its storage period till the mechanical activation [17]). Such relatively large amount of cement reduces the effectiveness of the dealing with the main problem - PG reprocessing, because when the amount of cement is increased, the amount of pozzolanic additive shall be increased accordingly as well. The energy input for the production of composite binding material is 
Table 1. Chemical composition of materials

\begin{tabular}{|c|c|c|c|c|c|c|c|c|c|c|c|c|}
\hline \multirow{2}{*}{ Material } & \multicolumn{12}{|c|}{ Content, mass $\%$} \\
\hline & $\mathrm{SO}_{3}$ & $\mathrm{CaO}$ & $\mathrm{Al}_{2} \mathrm{O}_{3}$ & $\mathrm{Fe}_{2} \mathrm{O}_{3}$ & $\mathrm{P}_{2} \mathrm{O}_{5 \mathrm{t}}$ & $\mathrm{P}_{2} \mathrm{O}_{5 \text { s.w }}$ & $\mathrm{F}_{\mathrm{t}}$ & $\mathrm{MgO}$ & $\mathrm{SiO}_{2}$ & $\mathrm{~K}_{2} \mathrm{O}$ & $\mathrm{Na}_{2} \mathrm{O}$ & LOI \\
\hline $\mathrm{PG}_{\mathrm{K}}$ & 52.21 & 37.16 & 0.15 & 0.12 & 1.46 & 0.38 & 0.49 & 1.43 & - & - & - & 6.61 \\
\hline $\mathrm{PG}_{\mathrm{MK}}$ & 51.11 & 34.35 & 0.24 & 0.06 & 1.84 & 0.49 & 0.50 & 0.72 & 4.35 & - & - & 6.34 \\
\hline $\mathrm{O}$ & 0.37 & 16.27 & 1.83 & 0.74 & - & - & - & 0.12 & 66.07 & 0.24 & - & 14.35 \\
\hline Ms & 0.35 & 0.25 & 0.24 & 0.05 & - & - & - & 0.43 & 96.66 & 1.24 & 0.14 & 0.64 \\
\hline
\end{tabular}

measurable also because the cement is characterized by highest energy consumption.

In order to increase the effectiveness of the dealing with the PG reprocessing problem and to lower the energy consumption required for the production of binding material from $\mathrm{PG}$, it is expedient to analyse the physical mechanical and water resistance properties of PGCP compositions with less amount of cement, when freshly removed moist hemihydrate phosphogypsum is used, and to compare its properties with the properties of conventional water resistant PGCP compositions.

\section{MATERIALS AND METHODS}

Uncooled and unhydrated freshly removed from the conveyer PG of two types was used:

$-\mathrm{PG}_{\mathrm{K}}-$ produced from Kovdor apatite, temperature $63^{\circ} \mathrm{C}, \mathrm{pH}-2.64$;

$-\mathrm{PG}_{\mathrm{MK}}$ - produced from Morocco phosphorites $(80 \%)$ and Kovdor apatite $(20 \%)$, temperature $-66^{\circ} \mathrm{C}$, $\mathrm{pH}-2.46$.

Portland-lime cement CEM II/A-L 42.5 N (C) according with LST EN 197-1 was used. Specific surface area was $\sim 357 \mathrm{~m}^{2} / \mathrm{kg}$, clinker mineral composition was: $\mathrm{C}_{3} \mathrm{~S}-$ $63 \%, \mathrm{C}_{2} \mathrm{~S}-12 \%, \mathrm{C}_{3} \mathrm{~A}-9.5 \%, \mathrm{C}_{4} \mathrm{AF}-10.5 \%$.

Stoniškių quarry (Lithuania) carbonate opoka (O) (specific surface area $\sim 1400 \mathrm{~m}^{2} / \mathrm{kg}$, amount of active $\mathrm{SiO}_{2}$ $\sim 66 \%$, fine-dispersive carbonates $\sim 30 \%$ ) and microsilica (Ms), (specific surface area $\sim 2000 \mathrm{~m}^{2} / \mathrm{kg}$, amount of active $\mathrm{SiO}_{2} \sim 96 \%$ ) were used as pozzolanic additives.

Chemical composition of the used materials is given in Table 1.

The ratio pozzolana/cement $(\mathrm{P} / \mathrm{C})$, determined in the previous work [12] were used: $\mathrm{O} / \mathrm{C}=1.0 ; \mathrm{Ms} / \mathrm{C}=0.5$. The compositions of PGCP specimens are given in Table 2.

Mechanical activation of PG with additives was conducted in a disintegrator DIA-01 (3000 rpm of the activating disks). There was not added additional water. Prism-shaped samples $(4 \times 4 \times 16 \mathrm{~cm})$ were formed from the activated mass by vibrating without delay. The samples were held in the moulds for one day then were cured for following 27 day in the conditions of $100 \%$ relative humidity and at $20^{\circ} \mathrm{C}$. To determine the durability of hardened compositions the samples were divided into five groups cured as follows:

- under the same conditions (H conditions);

- in water at $20^{\circ} \mathrm{C}$, which was changed weekly (imitation of flowing water) (FW20 conditions), thus making it possible for ettringite to form;

- in water at $4{ }^{\circ} \mathrm{C}$, which was changed weekly (FW4 conditions). This is method suggested by Alksnis [15] to determine the resistance of GCP composition for thaumasite formation. Minimum testing time of 3 month corresponds to the time of thaumasite synthesis.

- in not changed water at $20^{\circ} \mathrm{C}$ (NW20 conditions) and $4{ }^{\circ} \mathrm{C}$ (NW4 conditions);

Table 2. Composition of PGCP samples

\begin{tabular}{|c|c|c|c|c|}
\hline \multirow{3}{*}{$\begin{array}{c}\text { Code } \\
\text { of samples }\end{array}$} & \multicolumn{4}{|c|}{ Composition, $\%$} \\
\hline & \multirow{2}{*}{$\begin{array}{l}\text { PG }\left(\mathrm{PG}_{\mathrm{K}}\right. \\
\text { or } \mathrm{PG}_{\mathrm{MK}}\end{array}$} & \multirow{2}{*}{$\mathrm{C}$} & \multicolumn{2}{|c|}{ pozzolanic additives $(\mathrm{P})$} \\
\hline & & & type & content \\
\hline $\operatorname{PGCO}(20)$ & 60 & 20 & $\mathrm{O}$ & 20 \\
\hline PGCMs $(20)$ & 70 & 20 & Ms & 10 \\
\hline $\mathrm{PGCO}(10)$ & 80 & 10 & $\mathrm{O}$ & 10 \\
\hline PGCMs (10) & 85 & 10 & Ms & 5 \\
\hline
\end{tabular}

The compressive strength was determined by testing of dried halves of the broken prism. Testing machine H2000KU Tensile Test Machine (Tinius Olsen Ltd) was used, the rate of load increase was $2400 \pm 200 \mathrm{~N} / \mathrm{S}$. The resistance to short-term impact of water (softening coefficient) was determined by immersing of dried samples in water for 2 days. The setting time was determined by using Vicat apparatus. $\mathrm{pH}$ control was carried out by using ionometer $\mathrm{pH}-330 \mathrm{i}$, when the ratio of solids and distilled water was $1: 10$. A diffractometer DRON-1, Fe-filtered Co $\mathrm{K}_{\alpha}(\lambda=0.17902 \mathrm{~nm})$ radiation was used for X-ray diffraction analysis.

\section{RESULTS AND DISCUSSION}

Properties of PGCP binders (formation masses) and dry samples (after 28 days of hardening in conditions $\mathrm{H}$ ) are given in Table 3. As seen, $\mathrm{pH}$ of all formation masses is alkaline, its values are similar, i. e. the amount of cement as well as the type of PG practically has no influence on the effectiveness for the neutralization of acidic impurities. Setting times of all composite binders also are similar. Slightly faster setting of binder with $20 \%$ cement and opoka, also of binder with $\mathrm{PG}_{\mathrm{MK}}$ can be explained by lower $\mathrm{W} / \mathrm{S}$ ratio and thicker consistency of formation mass.

When the amount of cement is increased from $10 \%$ to $20 \%$, density of samples increases and water absorption decreases. Water absorption depends also on the type of pozzolanic additive: sample with microsilica (PGCMs) in most of the cases are characterized by lower density than samples with opoka (PGCO), but their water absorption is smaller (Table 3). This positive influence of microsilica on the water absorption of hardened material comparing to opoka can be explained by the higher fineness and higher amount of amorphous $\mathrm{SiO}_{2}$, existing in it.

The softening coefficient values of all compositions are quite high $(>0.9)$ and these values of samples with 
Table 3. Chemical and physical properties of PGCP binders and hardened samples. Hardening time 28 days

\begin{tabular}{|c|c|c|c|c|c|c|c|c|c|c|c|c|c|c|}
\hline \multirow{4}{*}{ Composition } & \multicolumn{8}{|c|}{ Properties of binder } & \multicolumn{6}{|c|}{ Properties of hardened specimens } \\
\hline & \multirow{2}{*}{\multicolumn{2}{|c|}{$\begin{array}{l}\text { Water/Solids } \\
(\mathrm{W} / \mathrm{S})\end{array}$}} & \multirow{2}{*}{\multicolumn{2}{|c|}{$\mathrm{pH}$}} & \multicolumn{4}{|c|}{ Setting times, $\min$. } & \multirow{2}{*}{\multicolumn{2}{|c|}{ Density, $\mathrm{kg} / \mathrm{m}^{3}$}} & \multirow{2}{*}{\multicolumn{2}{|c|}{$\begin{array}{c}\text { Water } \\
\text { absorption, \% }\end{array}$}} & \multirow{2}{*}{\multicolumn{2}{|c|}{$\begin{array}{l}\text { Softening } \\
\text { coefficient }\end{array}$}} \\
\hline & & & & & \multicolumn{2}{|c|}{ initial } & \multicolumn{2}{|c|}{ final } & & & & & & \\
\hline & $\mathrm{PG}_{\mathrm{K}}$ & $\mathrm{PG}_{\mathrm{MK}}$ & $\mathrm{PG}_{\mathrm{K}}$ & $\mathrm{PG}_{\mathrm{MK}}$ & $\mathrm{PG}_{\mathrm{K}}$ & $\mathrm{PG}_{\mathrm{MK}}$ & $\mathrm{PG}_{\mathrm{K}}$ & $\mathrm{PG}_{\mathrm{MK}}$ & $\mathrm{PG}_{\mathrm{K}}$ & $\mathrm{PG}_{\mathrm{MK}}$ & $\mathrm{PG}_{\mathrm{K}}$ & $\mathrm{PG}_{\mathrm{MK}}$ & $\mathrm{PG}_{\mathrm{K}}$ & $\mathrm{PG}_{\mathrm{MK}}$ \\
\hline $\mathrm{PGCO}(20)$ & 0.24 & 0.22 & 11.7 & 11.6 & 25 & 22 & 55 & 45 & 1740 & 1790 & 7.4 & 6.8 & 0.94 & 0.94 \\
\hline PGCMs (20) & 0.26 & 0.23 & 11.8 & 11.8 & 30 & 30 & 60 & 55 & 1690 & 1770 & 6.9 & 5.9 & 0.96 & 0.97 \\
\hline PGCO(10) & 0.26 & 0.23 & 11.2 & 11.3 & 32 & 25 & 60 & 60 & 1660 & 1750 & 10.4 & 9.7 & 0.91 & 0.93 \\
\hline PGCMs (10) & 0.26 & 0.23 & 11.4 & 11.2 & 36 & 28 & 70 & 65 & 1680 & 1720 & 9.6 & 9.0 & 0.92 & 0.94 \\
\hline
\end{tabular}

$20 \%$ cement $(\mathrm{PGCP}(20))$ are only slightly higher than of samples with $10 \%$ cement $(\mathrm{PGCP}(10))$. This indicates what mechanically activated PG compositions with $10 \%$ cement is also resistance to short-term impact of water. Such high water resistance is determined by dense and solid microstructure of the samples and low porosity of the matrix, because during the mechanical activation not only the porous hollow structure of PG particles, as well as particles' agglomerates, are destroyed (this allows us to reduce the amount of water required for the mixing), but also the components are fully mixed, their interaction is improved. As it is well known, the porosity is one of the main parameters determining strength, water resistance and other durability properties of the gypsum products [18-20]. The softening coefficient of samples with opoka is slightly lower than the one with microsilica.

Even with the large amount of cement (for instance $20 \%$ ), gypsum cement pozzolanic compositions are not ranked as resistant to the long-term influence of water $[5,15]$ and strength properties are evaluated in accordance with the hardening in the humid environment (condition $\mathrm{H}$ ) [14]. As seen, the strength of PGCP(10) samples is lower than PGCP(20) samples (Fig. 1, a). The growth of strength of PGCP(10) samples continues 3 months and after it stops or almost stops. Noticeable strength's growth of the PGCP(20) samples continues longer ( 6 months) and its strength is $25 \%-30 \%$ higher than PGCP(10) samples. The type of pozzolanic additive used also influences the strength of the hardened PGCP. PGCO have slightly lower strength $6 \%-10 \%$ than the PGCMs. This is explained by considering two reasons. Firstly, the lower amount PG exists in the PGCO (Table 2) and the material is more diluted by the filler aggregate. Secondly, the amount of $\mathrm{SiO}_{2}$ in microsilica reaches $96.7 \%$, in opoka - only $66.1 \%$ (Table 1), in addition, the reactivity of microsilica is much higher than opoka [21], due to the formation of calcium hydrosilicates in PGCMs should be faster than in PGCO compositions. The influence of $\mathrm{PG}$ type is not considerable, slightly higher strength compositions with $\mathrm{PG}_{\mathrm{MK}}$ comparing to the one with $\mathrm{PG}_{\mathrm{M}}$ can be explained by lower $\mathrm{W} / \mathrm{S}$ ratio in formation mass and higher density of specimens (Table 3 ).

Data, provided in Fig. 1, b and c, shows, that kinetics of the strength variation of the samples stored in changed and not changed water (conditions FW and NW) is different, i. e., the faster strength loss was carried out in changed water. Resistance to long-term impact of water of PGCP(10) is lower than PGCP(20). At NW20 conditions the strength of all PGCP(20) samples increases during 3 months, and only after 4 months slightly decreases.
Strength of PGCP(10) samples decreases by third already within 1 month, and $\sim 3$ times within 4 months. PGCMs samples are more resistant to the long term influence of water than PGCO samples, as it is in case of short term influence of water (Table 3). At FW20 conditions, the strength of all samples decreases faster and within 4 months the strength of PGCP(20) samples decreased by $40 \%-60 \%$, and PGCP(10) samples lost their strength at all. During our previous investigations [22, 23], where GCP and ACP (G and A - binder from natural gypsum and anhydrite, respectively) with $20 \%$ of cement were investigated, it was determined that at $\mathrm{FW}(20)$ conditions, the strength of GCP decreased only by $\sim 10 \%$, and the strength of ACP even slightly increased. It must be noted, that GCP and ACP samples, formed by moulding from plastic mass, were used for research, and their density was lower $\left(1100 \mathrm{~kg} / \mathrm{m}^{3}\right.$ and $\left.1400 \mathrm{~kg} / \mathrm{m}^{3}\right)$, i.e. porosity was much higher than the one of PGCP samples investigated in this research (Table 3). It is obvious that due to the specific morphology and high fineness of PG crystals, despite the mechanically activation of PGCP the gypsum frame of hardened compositions is much more poorly protected by the products of cement hydration than the frame formed from the binders of natural gypsum or anhydrite with much more dense crystal structure.

The results of X-ray diffraction analysis of PGCO and PGCMs, hardened at FW20 conditions, show that these compositions are resistant to the formation of ettringite $(\mathrm{E})$. Diffraction peaks of primary $E$ are visible only in X-ray patterns of PGCO and the intensity of these peaks do not vary throughout the period of 4 months (Fig. 2, a and b). There are no $\mathrm{E}$ diffraction peaks visible in the $\mathrm{X}$-ray patterns of PGCMs (Fig. 2, c). As it is known, primary E, that is formed during the first stage of cement hydration, does not have destructive influence, moreover, primary $\mathrm{E}$ even strengthens and compacts the hardened structure being formed [24]. However, at certain conditions (low positive temperature, humidity, ions of carbonate) presence of $E$ can stimulate the formation of other destructive mineral - thaumasite ( $T$ ) [25]. Thaumasite is even more harmful, because it can form in the compositions with sufficient amount of pozzolanic additive as well [15].

This was also confirmed during the investigations of PGCP samples stored at NW4 and FW4 conditions. Fig. 1, c, shows that the strength of $\operatorname{PGCO}(20)$ samples, stored at NW4 conditions, decreased by more than $30 \%$ within one month, and $20 \%$ - within 3 months, stored at FW4 conditions - respectively $\sim 60 \%$ and $\sim 95 \%$. These samples practically fully disintegrated within 4 months.

Visually it was possible to see that samples stored in 


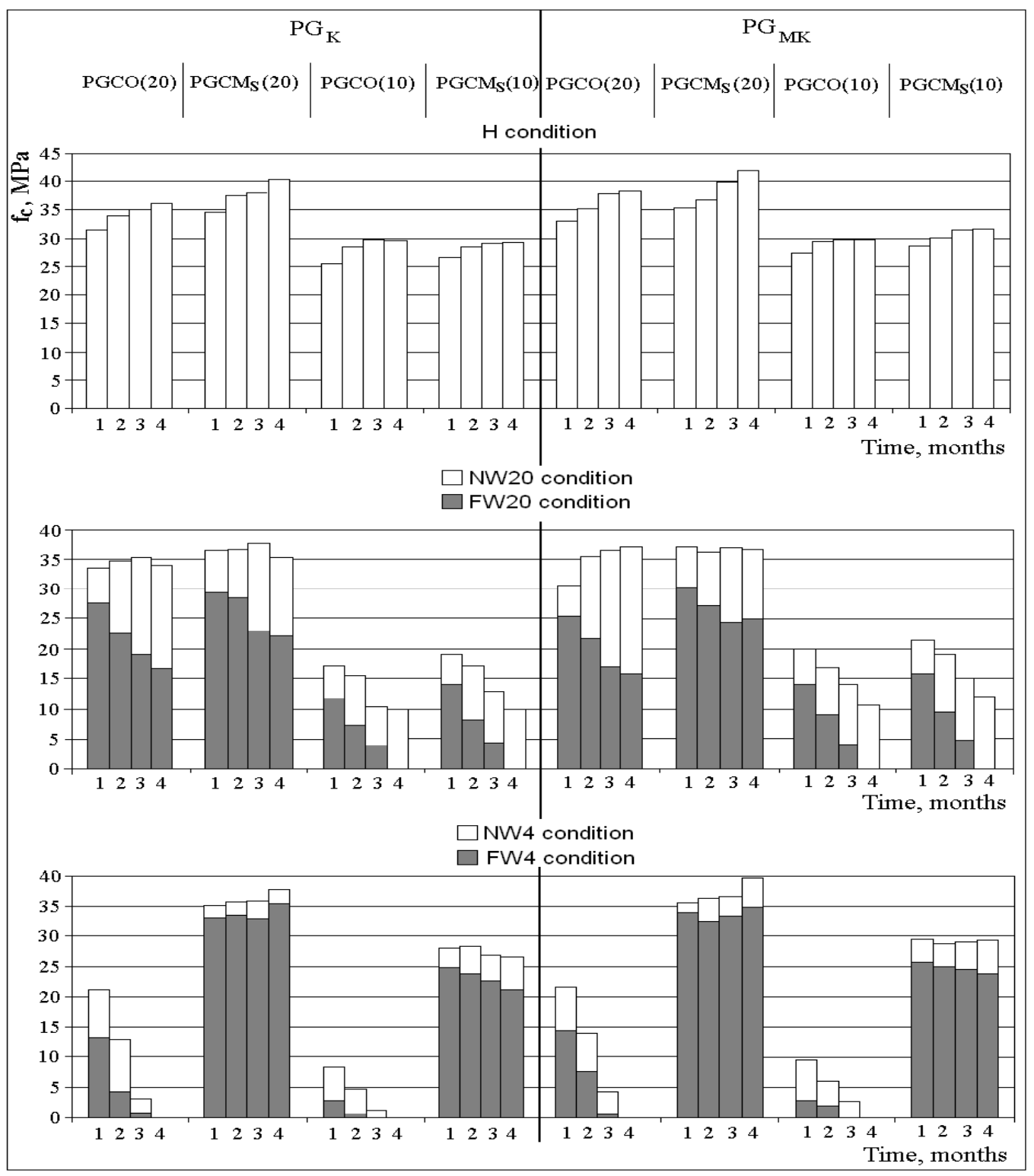

Fig. 1. Variation of compressive strength of PGCP samples, stored in different conditions

NW4 condition were slightly bloated and crumbled, by leaving the harder core inside (Fig. 3, a), and samples stored in FW4 conditions were disintegrated fully (Fig. 3, b). The strength of PGCO(10) samples was decreasing much faster, and at FW4 conditions they disintegrated within 3 months, at NW4 conditions - they practically lost their strength within 3 months, and disintegrated within 4 months. The X-ray diffraction analysis of disintegrated samples showed that formation of thaumasite took place (Fig. 2, d). Thaumasite was formed also in PGCO samples, stored throughout winter in the unheated room. The edges of samples were periodically watered. In this case the thaumasite was formed locally, i.e. on the watered areas (Fig. 3, c).

No thaumasite was formed in PGCMs samples, stored at NW4 and FW4 conditions. When the mineral composition of PGCO and PGCMs compositions being hardened is compared, it can be stated that the formation of thaumasite in PGCO compositions is stimulated by the primary ettringite and large amount $(\sim 30 \%)$ of fine dispersive carbonates existing in the opoka [26]. During our previous investigations [22, 23] it was determined that analogous GCO compositions (G - gypsum binder from natural gypsum) are resistant to the formation of thaumasite, despite the presence of primary ettringite as well as fine dispersive carbonates. This once more confirms the statement that the specific properties of PG binder have influence on the creation of destroying minerals in the compositions of gypsum cement and pozzolana.

Strength variation of PGCMs samples, stored at NW20, FN20, NW4, FW4 conditions, shows that water resistances of the samples is higher in lower temperatures (Fig. 1, c) Due to the slower hardening of cement component in lower temperature, hardening of the compositions lasts longer period. For instance, the strength of PGCMs(20) samples, stored at NW4 conditions, was increasing throughout the period of 4 months.

Additionally, the softening processes of gypsum frame become slower in lower temperature. This is reflected the best by variation of the strength of the samples with the lower amount $(10 \%)$ of cement in the water of various 


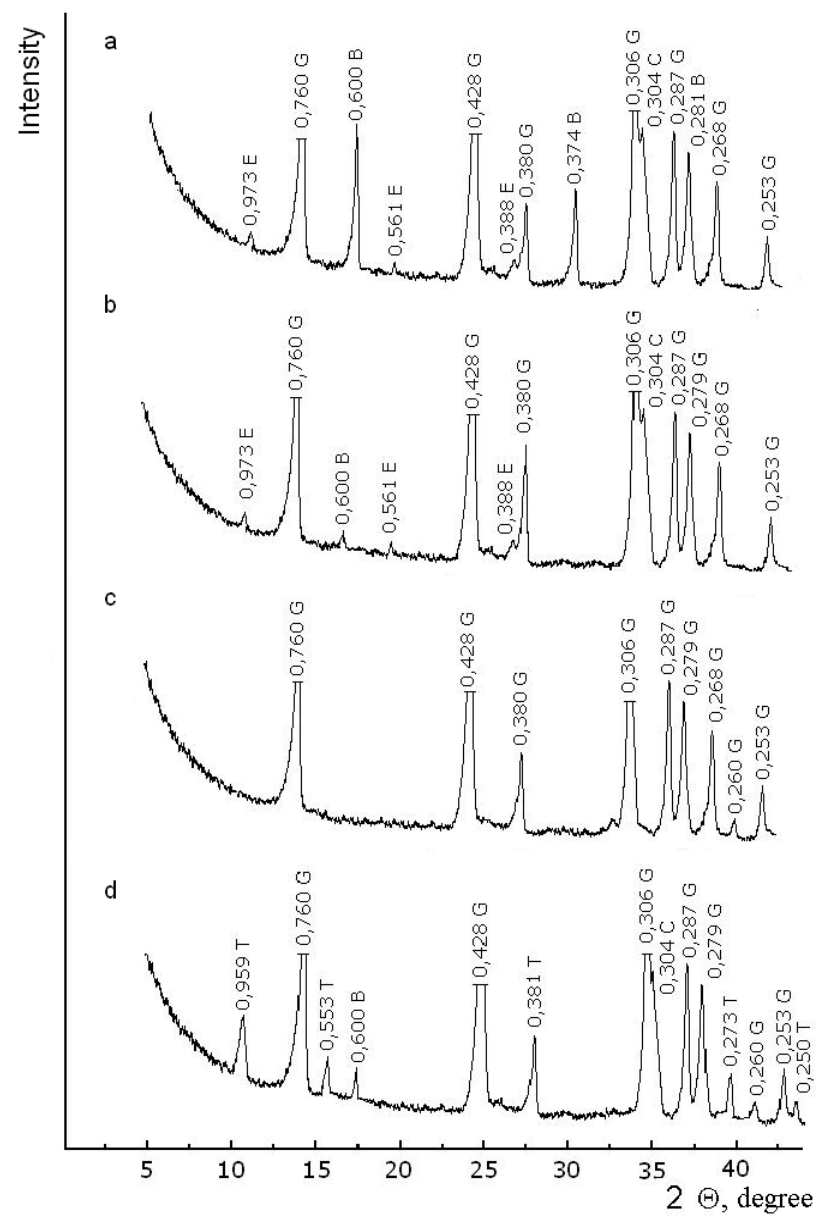

Fig. 2. X-ray diffraction patterns of hardened samples: a - PGCO $(20)$ after 1 days storage at $H$ conditions; $b$, c - PGCO(20) and PGCMs(20), respectively, after 4 months storage at $\mathrm{FW}(20)$ conditions; d - PGCO(20) after 4 months storage at FW(4) conditions; $\mathrm{G}$ - gypsum; B - bassanite; $\mathrm{C}$ - calcite; E - ettringite; T - thaumasite

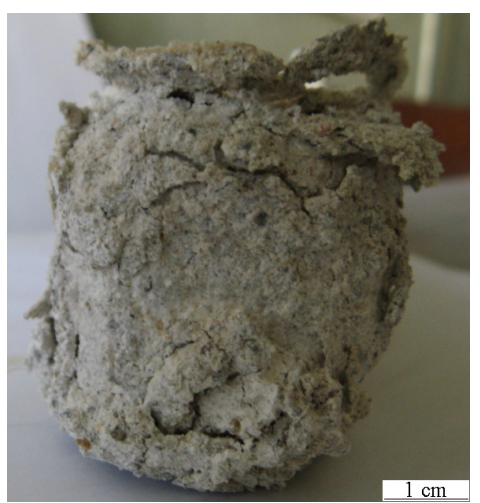

a

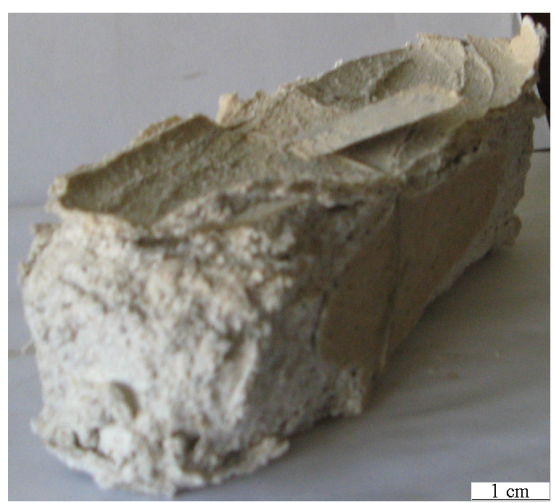

$\mathrm{b}$

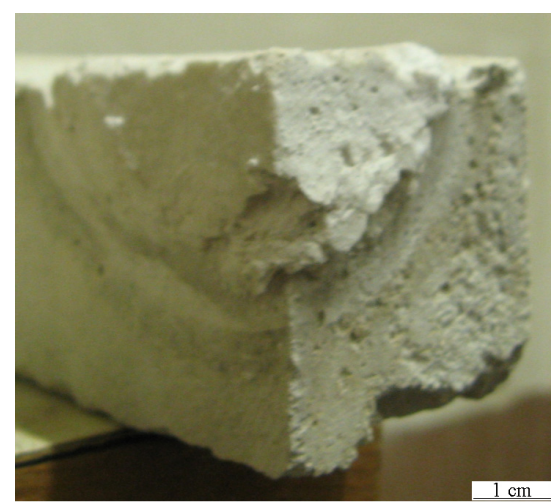

Fig. 3. View of PGCO(20) samples: a - stored at NW4 condition; b - stored at FW4 condition; c - locally formation of thaumasite

temperatures: variation of the strength of $\operatorname{PGCMs}(10)$ samples, stored at NW4 conditions, remained stable throughout the period of 2 months decreased less than $10 \%$ within 4 months. In case of storage at NW20 conditions, the strength decreased respectively by $\sim 30 \%$ and $\sim 70 \%$. In case of storage at FW4 conditions, the strength decreased by $\sim 10 \%$ within 4 months, and for the case of FW20 conditions, the samples completely lost their strength. Type of raw materials from which PG binders $\left(\mathrm{PG}_{\mathrm{K}}\right.$ or $\left.\mathrm{PGM}_{\mathrm{K}}\right)$ was obtained does not have a large influence on the water resistance and variation of strength in different conditions (Fig. 1), also on the mineral composition of hardened PGCP.

\section{CONCLUSIONS}

PGCP samples, formed by vibrating from the stiff mixture of the mechanically activated fresh hemihydrate phosphogypsum, cement and pozzolanic additive (opoka or microsilica), are characterized by high strength, low porosity, and they are resistant to the moisture and shortterm influence of water. After 28 days of hardening in the humid environment, the strength of the samples with the 
amount of cement of $20 \%$ and $10 \%$ was $32 \mathrm{MPa}-$ $35 \mathrm{MPa}$ and $25 \mathrm{MPa}-29 \mathrm{MPa}$, water absorption - $(5.9 \%-$ $7.4 \%$ and $9.0 \%-10.4 \%$, softening coefficient $-0.94-$ 0.97 ir $0.91-0.94$ respectively.

Physical and mechanical as well as durability properties of PGCP depend not only on the amount of cement, but also on the type of pozzolanic additive used. PGCP with microsilica, which amount, due to the higher reactivity, must be twice lower comparing to the amount of opoka, are characterised by higher strength, lower porosity, and it is more resistant to the influence of water.

The hardened PGCMs ir PGCO are resistant to formation of destructive mineral ettringite. However, the primary ettringite found in PGCO compositions and high amount of fine carbonates in opoka stimulates the formation of other destructive mineral - thaumasite at low positive temperature and humidity. In PGCMs compositions the primary ettringite or is not formed, or its amount is very low and not detectable by X-ray.

The type of raw materials from which waste hemihydrate phospogypsum was obtained has no large influence to properties of mechanically activated PGCP compositions.

\section{REFERENCES}

1. Leškevičienė, V., Nizevičienė, D., Valančius, Z. Formation and Properties of Semihydrate Calcium Sulphate Crystals Materials Science (Medžiagotyra) 7 (2) 2001: pp. 116-122.

2. Singh, M. Role of Phosphogypsum Impurities on Strength and Microstructure of Selenite Plaster Construction and Building Material 19 (6) 2005: pp. 480-486.

3. Valančius, Z., Nizeviciene, D., Leskeviciene, V., Kybartiene, N. Influence of the Technological Parameters on the Structure and Properties of Hemi-hydrate Phosphogypsum Ceramics-Silicaty 49 (2) 2005: pp. $120-125$.

4. Volzhenskij, A. V., Burov, J. S., Kolokolnikov, V. S. Inorganics Binding Materials. Moscow: Strojizdat, 1979: 479 p. (in Russian).

5. Ferronskaja, A. V. The Durability of Gypsum Materials, Products and Structures. Moscow: Strojizdat, 1984: 256 p. (in Russian).

6. Colak, A. The Long-term Durability Performance of Gypsum - Portland Cement - Natural Pozzolan Blends Cement and Concrete Research 32 (1) 2002: pp. 109-115.

7. Rimkevičius, M. Gypsum - Cement Binder from Mechanically Activated Extractive Semi-hydrate Phosphogypsum Summary of Doctoral Dissertation Vilnius, 2003: 34 p. (in Lithuanian).

8. Kaminskas, A., Rimkevičius, M. Extractive Semi-hydrate Gypsum (E - $\left.\mathrm{CaSO}_{4} \quad 0.5 \quad \mathrm{H}_{2} \mathrm{O}\right) \quad$ Materials Science (Medžiagotyra) 6 (4) 2000: pp. 325-329.

9. Kaminskas, A., Pričkaitienè, J., Rimkevičius, M., Špokauskas, A. Investigations of Water Resistance of Samples Made from Extractive Semi-hydrate Gypsum Materials Science (Medžiagotyra) 7 (1) 2001: pp. 44-47.

10. Kaminskas, A., Gaidučis, S., Mačiulaitis, R. Influence of Granulated Milled Slag Glass Additive on Hemihydrate
Phosphogypsum Hardening Materials Science (Medžiagotyra) 13 (3) 2007: pp. 224-228.

11. Gaidučis, S.; Mačiulaitis, R.; Kaminskas, A. Ecobalance Features and Significance of Hemihydrate Phosphogypsum Reprocessing into Gypsum Binding Materials Journal of Civil Engineering and Management 15 (2) 2009: pp. $205-213$.

12. Žvironaitė, J., Gaidučis, S., Kaminskas, A., Mačiulaitis, R. Hydration and Hardening of Composite Binder Containing Mechanically Activated Hemihydrate Phosphogypsum Materials Science (Medžiagotyra) 14 (4) 2008: pp. 356-360.

13. Gaidučis, S., Žvironaitė, J. Influence of Mechanical Activation on Hardening Structure of Composite Phospogypsum Binder Chemical Technology (Chemine technologija) 1 2009: pp. 69-75 (in Lithuanian).

14. TU 21 31-62-89 Gypsum Cement Pozzolana Binder. Specifications (in Russian).

15. Alksnis, F. F. Hardening and Destruction of Gypsum Cement Composite Materials. Leningrad: Strojizdat, 1988: 103 p. (in Russian).

16. Bellmann, F., Stark. J. The Role of Calcioum Hydroxide in the Formation of Thaumasite Cement and Concrete Research 38 (2) 2008: pp. 154-161.

17. Gaidučis, S. Mechanical Activation and Additives Influence on Extractive Hemihydrate Phosphogypsum and its Products Characteristics Summary of Doctoral Dissertation Vilnius, 2010: $24 \mathrm{p}$.

18. Singh, M. Garg, R. Relatioship between Mechanical Properties and Porosity of Water-resistant Gypsum Binder Cement and Concrete Research 26 (1) 1996: pp. 449-456.

19. Hernandez, F., Trivino, F., Menendez, I. Reducing the Porosity of Hardened Hemihydrate Plaster by Impregnation with Salt Solution ZKG International 7 1996: pp. $408-411$.

20. Sattler, H. The Importance of Porosity for the Properties of Hardened Gypsum Plaster Products ZKG International 1 1997: pp. $54-62$.

21. Vektaris, B., Vilkas, V. Investigation of Silica Fume Activity Materials Science (Medžiagotyra) 7 (2) 2001: pp. $123-126$.

22. Žvironaitè, J., Lasys, A. Investigations of Composite Anhydrite - Cement - Pozzolana Binding Material Tile and Brick International 14 (3) 1998: pp. 176-184.

23. Žvironaitè, J., Kerienè, J. Influence of the Sulphate Component Kind on Properties of Gypsum-CementPozzolana Binding Materials Chemical Technology (Chemine technologija) 2 (8) 1998: pp. 23-28 (in Lithuanian).

24. Collepardi, M. A State-of-Art Review on Delayed Ettringite Attack on Concrete Cement and Concrete Composites 25 (4-5) 2003: pp. $401-407$.

25. Kohler, S., Heinz, D., Urbonas, L. Effect of Ettringite to Thaumasite Formation Cement and Concrete Research 36 (4) 2006: pp. 697-706.

26. Irassar, E. F. Sulfate Attack on Cementious Materials containing Limestone Filler - A Review Cement and Concrete Research 39 (3) 2009: pp. 241-254. 